\title{
WHAT IS A POSTMODERN CONSTITUTIONALISM?
}

\author{
J.M. Balkin **
}

I

I begin with a puzzle. It must certainly strike one as odd that the subject of postmodern constitutional law arises at a time when the actual arbiters of the Constitution - the federal judiciary and in particular the Supreme Court of the United States - appear to be more conservative than they have been for many years, and indeed, are likely to remain so for the foreseeable future. Postmodernism is often associated with what is new, innovative, and on the cutting edge of cultural development. Yet if we were to define the elements of a postmodern constitutional culture, it would be clear that one of the most central features of the present period - if the expression "central" still has any remaining currency in an era of postmodernism - is a judiciary which has no intention of being new or innovative in anything. Its intellectual leader, Justice Scalia, has even called for a constitutional jurisprudence of tradition, coupled with a return to an interpretive theory of plain meanings for statutes and original intention with respect to the Constitution. ${ }^{1}$

To be sure, some might be tempted to explain away this phenomenon as an anomaly or an exception. The federal judiciary, they will say, is behind the times, much as the Lochner-era justices were. Eventually, when a different administration comes to power, and appoints new judges, the judiciary will catch up with the breathtaking developments we now discuss under the name of "postmodern" jurisprudence. Indeed, all about us we see, in the works of legal commentators and scholars, and even in the speeches of a few enlightened political leaders, the harbingers of a new dawn of constitutional postmodernism.

* Charles Tilford McCormick Professor of Law, University of Texas. - Ed. This essay was presented at a conference on postmodern constitutional law at Georgetown University, and I thank the participants for their comments; my special thanks to Pierre Schlag and Steven Winter for their valuable criticisms of an earlier draft.

1. See, e.g., Michael H. v. Gerald D., 491 U.S. 110 (1989); Green v. Bock Laundry Mach. Co., 490 U.S. 504, 527, 528-29 (1989) (Scalia, J., concurring); Blanchard v. Bergeron, 489 U.S. 87, 97-100 (1989) (Scalia, J., concurring); Antonin Scalia, Originalism, The Lesser Evil, 57 U. CIN. L. Rev. 849 (1989). 
The current climate of the federal judiciary is an aberration, a mistake which hinders the progress of a grand new postmodern day.

Nevertheless, I think the attempt to see a postmodern constitutional jurisprudence in opposition to the increasingly conservative practice of constitutional law is mistaken. It is understandable why postmodern theorists might wish to identify postmodernism with the progressive, with the new that will eventually replace the old, and deny that title to the work of the Rehnquist Court and the rest of the Reagan judiciary. Yet to treat constitutional law as it is actually practiced by courts as foreign or exceptional to a postmodern era or as the target of an eventual postmodern revolution fails fully to grasp the meaning of postmodernism as a feature of current culture. Moreover, I think that such an attempted marginalization would be ironic coming from those who claim to adopt a postmodern (and especially poststructuralist) stance. Rather than seeing this political phenomenon as exceptional or aberrational to postmodern constitutional culture, I think we should see it as exemplary of that culture. Postmodern constitutionalism is the constitutionalism of reactionary judges surrounded by a liberal academy that despises or disregards them, and which is despised and disregarded in turn; postmodern constitutional culture is the culture in which the control of constitutional lawmaking apparatus is in the hands of the most conservative forces in mainstream life, while constitutional law as practiced in the legal academy has cast itself adrift, whether out of desperation, disgust, or despair, and engaged itself in spinning gossamer webs of republicanism, deconstruction, dialogism, feminism, or what have you. Postmodern legal culture is the rout of progressive forces, the increasing insularity, selfabsorption, and fragmentation of progressive academic writing, and the increasing irrelevence of that writing to the positive law of the U.S. Constitution.

How is this possible? What does postmodernism mean if Chief Justice Rehnquist already presides over the postmodern Supreme Court? What is the promise of postmodernism or of postmodern constitutionalism in such an age? We can resolve this puzzle if we dispel certain notions about what postmodernism is and what is or should be our relationship to it.

We must distinguish several different facets of postmodernism. First, postmodernism is the cultural era in which we live - the era of 
postmodernity. ${ }^{2}$ It is in some ways a furtherance of and in other ways an outgrowth of and reaction to an earlier epoch called modernity. Like modernity, it combines changes in politics, art, and philosophy with changes in technology and methods of economic production. ${ }^{3}$ In particular, while modernity is often associated with the Industrial Revolution and mass production of material goods, postmodernism is better identified with the rise of mass forms of communication and the commodification of intellectual products and symbolic forms. ${ }^{4}$ It is the era of mass culture and mediazation, a term used to describe the ways in which culture and cultural artifacts are adapted to or created for the forms of mass communication. 5 Postmodernism in this sense is neither necessarily a good thing nor a bad thing. It is a cultural moment that needs to be interpreted and understood. In this sense, postmodernism, like modernism, embraces all who live within a culture, comprehending the fact that people will react to changes in society in many different ways.

Furthermore, it is important to recognize that the postmodern epoch as such is already upon us. Postmodernism is a cultural phenomenon that has already happened and that we are only becoming aware of now. Cultural change occurs as we live within a culture, but we only become aware of its full import later. Cultural understanding always works in retrospect. ${ }^{6}$ For us to speak of postmodernism as a coherent cultural episode in our lives, it must have already occurred; it must already be a part of our existence, albeit something that we are only now coming to codify, analyze, and understand. By the time that

2. See David harvey, The Condition of Postmodernity: AN Enquiry into the Origins of Cultural Change (1989); Fredric Jameson, Postmodernism, or, the CulTURAL Logic OF LATE CAPITALISM (1991); JEAN-FRANÇOIS LyOTARD, THE POSTMODERN CONDITION: A REPORT ON KNOWLEDGE (Geoff Bennington \& Brian Massumi trans., 1984).

3. See HARVEY, supra note 2.

4. Different versions of the "information society" thesis can be found in DANIEL BELL, THE Coming of Post-Industrial Society (1973); James R. Beniger, The Control RevoluTION: TECHNOLOGICAL AND ECONOMIC ORIGINS OF THE INFORMATION SOCIETY (1986); and Wilson P. Dizard, JR., The Coming Information Age: AN Overview of TeCHNOLOGY, ECONOMICS, AND Polmincs (2d ed. 1985). On the concept of "symbolic forms," see JoHN B. THOMPSON, IDEOLOGY AND MODERN CULTURE 136-45 (1990).

5. ThOMPSON, supra note 4, at 3-4, 11-20. The "photo opportunity," the televised criminal trial, and radio call-in show are all examples of mediazation. The rise of mass forms of electronic communication, including broadcast and cable television, satellite communication and computer networks, is central to understanding the transformation of culture brought about by postmodernity. For a pessimistic view of the consequences of mediazation on politics and culture generally, see Jean Baudrillard, For a CRITIQUe of the Political Economy of the Sign 164-84 (Charles Levin trans., 1981).

6. See Arthur C. Danto, Analytical Philosophy of History 168 (1965); Hans-GeORG GADAMER, TRUTH AND METHOD 179 (1975). The most famous expression of this principle is Hegel's metaphor of the Owl of Minerva, which spreads its wings only after night has fallen. Hegel's Philosophy of Right 13 (T. M. Knox trans., 1967). 
we understand postmodernism, postmodernism itself will already have been transformed into something quite different. We will then be enmeshed in a new cultural ethos of which we will be only dimly aware, not fully conscious of the elements of social life by which we are defined and by which later generations will define us. The best that we can hope to do is to define the present age by extrapolation from what is immediately past, which we can begin to understand and synthesize.

Second, postmodernism is also the set of cultural products created during the era of postmodernity. These cultural products reflect this era in different ways. Some are mimetic. If the postmodern era is an era of fragmentation, diffusion, emphasis on surface (as opposed to substance or as substance itself), then we might expect to see fragmentation, diffusion, and emphasis on surface in cultural artifacts of the postmodern period. And we do find this, for example, in the development of the music video. ${ }^{7}$ Some elements of postmodern culture, far from being mimetic of postmodernism, will be reactions to it, just as Romanticism was a reaction to the perceived deadening of modern life brought on by the Industrial Revolution. Often, however, the reaction will include cultural forms that are mimetic of postmodern cultural themes in an unintended and uncanny way. Thus, in the postmodern period we see a renewed interest in "natural" foods and health, and "natural" experiences, which, when viewed more closely, turn out to be high-tech, mediaized, or commodified. The back-to-nature enthusiast who purchases an expensive backpack constructed of artificial fibers, who eats food advertised as containing "all natural ingredients" that is mass produced and preserved in sealed plastic wrappers, and who exercises using the latest electronically monitored cycling machine, reinscribes elements of postmodernism even as she reacts to them. "Health" and "naturalness" become not only focal points of reaction to postmodern life, but also symbols subject to commodification and consumerist manipulation. Nor is this unintentional reinscription of postmodernist culture unique to the food and health industries. The devotee of "authentic performances" in music is able to enjoy them because of recording technology wholly alien to the circumstances in which early music was first performed, a technology that allows her (for example) to experience "authentic" performances

7. Steven CONNOR, Postmodern CUlture 160-61 (1989) (noting that juxtaposition of images within videos as well as juxtaposition of rock images from different decades "flatten[s] rock history into an undifferentiated present"). On MTV's connections to postmodernism generally, see E. ANn Kaplan, Rocking AROUND the Clock: Music Television, PostmodernISM, AND CONSUMER CULTURE 49-88 (1987). 
of church music repeatedly on her car stereo. ${ }^{8}$ The politician who aspires to avoid the artificiality of Washington politics and to mount an appeal to "the people" campaigns through a combination of sound bites and photo opportunities. Her private life is carefully reconstructed for public display.

Postmodernism understood as the products of a cultural era is not something uniformly to be prized. Postmodernism as a cultural phenomenon is not necessarily progressive or morally valuable. There is no guarantee that postmodernism will prove to be "politically correct" (this phrase itself, and its use to attack progressivism, are products of the postmodern era). If we recall, modernism itself was not progressive in all of its implications. Modernism brought us industrial methods of mass production and undreamed of technological progress. Modernism also brought us the Holocaust. 9 Like modernism before it, postmodernism is morally ambiguous. MTV is a paradigmatically postmodern phenomenon in its style of pastiche, fragmentation, and mediazation. It is also often violent, mindless, and misogynistic, and many critics fear that it conveys and reinforces these attitudes in the minds of its viewers. The 1988 presidential campaign was the essence of postmodern politics. It featured intensive mediazation of messages and symbols, lack of mass participation except as consumers of these symbols, emphasis on the surface features of political discourse and, indeed, the swallowing of substance by surface, so that surface became the substance of political discourse. The self-referential quality of postmodernist experience was well demonstrated by ubiquitous political polls that came to reflect not only what people thought about events, but what people expected that they and other people would think about events.

The management and manipulation of "photo opportunities" and "media events" had previously been honed throughout the eight years of the Reagan presidency. ${ }^{10}$ This presidency, in turn, was led (if that is the proper word) by an actor who played the role of a president, or

8. See Sanford Levinson \& J.M. Balkin, Law, Music, and Other Performing Arts, 139 U. PA. L. REV. 1597, 1622 (1991).

9. The degeneration of modernity into dehumanizing wickedness is the famous argument of

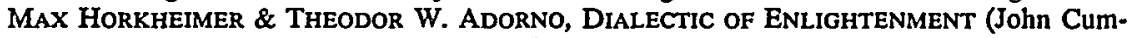
ming trans., Herder and Herder 1972) (1944).

10. On the Reagan administration's development of highly effective methods of media manipulation, see MARK HeRTSGaARd, ON BENDEd KNEE: THE PRESS AND THE REAGaN PresIDENCY (1988); Douglas Kellner, Television AND THE CRISIS OF Democracy 134-42 (1990); DONALD T. REGAN, FOR THE RECORD (1988). On the Reagan administration's use of staged media events and political spectacle, see TIMOTHY W. LUKE, SCREENS OF POWER (1989); Jochen Schulte-Sasse, Electronic Media and Cultural Politics in the Reagan Era, CULTURAL CRITIQUE, Winter 1987-88, at 123. 
rather the role of an actor playing the role of a president, with such bravado that it became difficult to tell the difference between role playing and the real thing. This was a president who so confounded distinctions between surface and substance, between smoke and mirrors and actual events, between real economic development and the creation of fictitious capital financed by a mountain of debt, that it was at last quite impossible to discern what had actually happened during the eight years of his presidency. Thus, for those who desire a postmodern politics, a word of warning: We have already lived through the postmodern presidency; we have already seen the rise of the postmodern presidential campaign. All of this must give anyone who celebrates postmodernism pause. To label something postmodern in this sense, then, is not to hold it up as a model to anyone who wants to be intellectually fashionable, but rather to present it as a cultural event that needs to be studied to understand how culture has changed for better or worse. This done, we must then ask how, given the changes in political culture wrought in the postmodern era, we can make politics better.

This cultural or sociological understanding of the concept of postmodernism is comparatively straightforward, even if the boundaries of the concept are debatable. However, there is a third meaning to postmodernism. Postmodernism is also a set of critical or theoretical claims about how art should be created, or how philosophy should be written (or not written at all!) - a set of general perspectives for interpreting and evaluating culture and the products of culture. ${ }^{11}$ The postmodern architect embraces decorative play and decentering; the postmodernist art critic attempts to find postmodern themes in the works of postmodern artists. ${ }^{12}$ In this sense, postmodernism is an interpretive practice that is claimed to be artistically or theoretically valuable or beneficial. Postmodernism is something to be celebrated or encouraged rather than simply an epoch to be understood. It is also associated with being on the cutting edge of cultural production or the interpretation or criticism of cultural production. In philosophy, postmodernism is an attack on what are called "totalizing" theories or "master narratives" that seek to explain all or substantially all of soci-

11. E.g., LYOTARD, supra note 2; RICHARD RORTY, CONTINGENCY, IRONY, AND SOLIDARITY (1989); Universal Abandon? The Politics of Postmodernism (Andrew Ross ed., 1989). For jurisprudential applications, see Costas Douzinas ET AL., PostModern JurISPRUDENCE: THE LAW OF TEXT IN THE TEXTS OF LAW (1991).

12. On the postmodern theory of architecture, see Charles Jencks, The LaNGuage of POST-MODERN ARCHITECTURE (1977). A recurring feature of postmodern art is the "attempt to dissolve the boundaries between 'high' and 'mass' culture." Roy Boyne \& Ali Rattansi, The Theory and Politics of Postmodernism, in Postmodernism AND SocIeTY 1, 9-10 (Roy Boyne \& Ali Rattansi eds., 1990). 
ety, history, knowledge, the nature of femininity, or virtually anything else within a comprehensive and articulable theory. ${ }^{13}$ From the perspective of postmodern philosophy, there is only a set of overlapping and occasionally conflicting "language games" that arise with respect to different spheres of social life, each incomplete and each constantly subject to alteration and development. ${ }^{14}$ The analogy to "games" is important because it is also characteristic of postmodern philosophy to view knowledge as an activity infused with social interaction and power rather than merely a set of articulable propositions or truths. ${ }^{15}$ Postmodern philosophy contrasts with relativism because conflicting perspectives are embedded in people's lives and activities; it contrasts with objectivism because it eschews the type of totalizing discourse that objectivism involves, as well as the reduction of knowledge to propositions and claims rather than action and power.

\section{III}

Thus, postmodernism is both a situation in which we find ourselves and a cultural response to that situation. Because the cultural response becomes part of the cultural situation, the two elements feed upon each other. Similarly, postmodernism is both a cultural situation and a set of claims about how that culture should be interpreted, altered and continued. Because such acts of interpretation, alteration and continuation stem from the culture, they share features in common with that culture.

Nevertheless, the overlapping meanings of postmodernism are liable to produce a number of confusions. The first is what we might call the "bandwagon" phenomenon. This is the attempt to celebrate or applaud certain features of cultural life simply because they are postmodern, or to believe that desirable forms of culture are produced by consciously attempting to incorporate postmodern themes. In short, it is the fallacy that conscious mimesis of postmodernism in the first two senses of that term - the cultural milieu and its products necessarily achieves postmodernism in the third sense - a set of cultural methods or goals that should be commended and pursued. Obvi-

13. See LyOTARD, supra note 2; Nancy Fraser \& Linda J. Nicholson, Social Criticism without Philosophy: An Encounter between Feminism and Postmodermism, in FEMINISM/PosTMODERNISM 19 (Linda J. Nicholson ed., 1990).

14. See LyotaRD, supra note 2 , at 10.

15. See Pierre Bourdieu, The Logic of Practice (Richard Nice trans., 1990); Pierre Bourdieu, Outline of a Theory of Practice (Richard Nice trans., 1977); Michel FouCault, The History of Sexuality - Volume 1: AN Introduction (Robert Hurley trans., 1978); Michel FouCAult, Power/KNOWLEDGe: SElected INTERviEWs \& OTHeR WRITINGS 1972-77 (Colin Gordon ed., 1980). 
ously, this can have highly undesirable effects. For example, one might be tempted to create a jurisprudence that is fragmented, celebrates surfaces, irony, and pastiche, and eschews master narratives because those are postmodernist themes and so that is what a postmodern jurisprudence should look like. This confuses postmodernism as a set of cultural phenomena that appear in a particular epoch with a set of criteria for judgment. The jurisprudence produced during the postmodern era will turn out to display elements of postmodernity whether this is consciously desired or not. That does not mean, however, that these are necessarily useful or desirable features of contemporary jurisprudence.

The second problem is the converse of the first. After hearing endless talk of postmodernist manifestos, it is easy to reduce postmodernism to a set of normative claims and thus forget that postmodernism also involves larger cultural forces that occur without any person particularly desiring their ascendancy. In his review of Fredric Jameson's book on postmodernism, Robert Post asserts that it is "obvious[] that postmodernism affects only certain segments of contemporary life."16 He offers as proof that there is "no postmodern physics, although there are postmodern accounts of physics. There is no postmodern medicine, although there are postmodern histories of medicine. There is no postmodern law, although there are postmodern commentaries on law."17 A modernist and proud of it, Post finds it impossible to translate the manifestos of postmodernists into actual practices that would make any sense in science, law, or medicine. How, or more significantly why, would anyone set out to eschew master narratives in physics, for example, or produce fragmentation in the practice of law or medicine? Thus, Post argues that although postmodernists can comment on these practices as outsiders, postmodernism can have no effect on the way they are actually performed. ${ }^{18}$

Nevertheless, it is important to distinguish between postmodernism as a set of normative standards and postmodernism as a cultural phenomenon. Even if one believes, as Post does, that postmodern normative claims are unsuited or inapplicable to certain social practices, it does not follow that the cultural forces we collectively label

16. Robert Post, Postmodern Temptations, 4 YALE J.L. \& Human. (forthcoming 1992) (reviewing JAMESON, supra note 2).

17. Id.

18. For a contrary view see Stephen Toulmin, The Construal of Reality: Criticism in Modern and Postmodern Science, in The Polmics of INTERPRETation 99 (W.J.T. Mitchell ed., 1983) (The standard opposition of norms of scientific theory construction to postmodern critical concepts is based on an idealized and outmoded view of scientific practice that does not adequately take into account what scientists actually do.). 
"postmodernity" have not affected these practices. To study these effects is not simply to give a "postmodern" account of them any more than to study the effects of modernity on social practices is to give a "modern" account of them. It is to ask rather how the forces that define any cultural age (whether modernity or postmodernity) affect the practices that take place within that age. In short, I argue that one does not have to be a postmodernist to recognize the pervasive effects of postmodernity in our lives.

The postmodern era is an era of industrial practices and mass organization and production applied not to material objects like automobiles but to the products of the mind - art and music, knowledge and information, accounting and other service industries. In this sense, it is quite clear that we are already witnessing postmodern legal and medical practice. The industrial model of production - where production is reinterpreted according to discrete units of production measurable in temporal or spatial categories - has already arrived in law. We already have the seventy-hour billed week, the canned brief, the 500-person law firm churning out mountains of paper to prove its value to its corporate clientele. We already have mass-produced litigation and mass-produced judicial administration to deal with it. Already most federal judicial opinions are written by twenty-five-year olds, so that the language of opinions does not really mean what it says, because it was not said by the persons whose meaning really counts. In medicine, we already have the industrial model of treatment - the structuring of medical practice around procedures that can be tabulated and described in reports to insurance companies, the physician who is rewarded not for her bedside manner but her ability to perform so many operations in an hour, and who bills accordingly. The age of the independent doctor has been replaced by that of the hospital bureaucrat. Older conceptions of professionalism have already been supplanted by an industrial model where service is defined in terms of discrete units of production that can be duplicated and evaluated on a mass scale. The lawyers let go by large New York law firms after the 1987 stock market crash quickly learned that employment practices in service sectors, and even in professional service sectors, had mutated into a model of employer-employee relations quite like those that Ford or General Motors applied to blue collar workers. ${ }^{19}$ Only cognitive resistance to recognizing this transformation led partners at these firms to engage in the disreputable claim that all of these attorneys were let go because they were not good lawyers, thus

19. See, e.g., Michael Orey, No Longer Risk-Free, AM. LAw., Dec. 1990, at 5 (noting changes in law firm thinking about hiring and firing of lawyers). 
preserving the rhetoric of a preindustrial professionalism to justify what were clearly profit-motivated layoffs. ${ }^{20}$ Likewise, the day of the individual scientist boldly grappling with the truths of the universe has given way to a complicated and bureaucratic model of research, where teams of scientists compete for institutional dollars and where scholarly factories are expected to produce a steady stream of papers as justification for their continued existence.

Perhaps the most confusing aspect of postmodernism is the postmodernist insistence on the relation between thought and action. This is a claim of postmodernist philosophy, a feature of postmodernist critical interpretation, and a fact about postmodern culture revealed by postmodern interpretations. The postmodern philosopher asserts that knowledge is always inscribed in a form of life; the historical experience of postmodernity is the unfolding of cultural phenomena that demonstrate the philosopher's claim. Thus, postmodernism is not merely an epistemological stance, nor is it merely a series of claims or statements about knowledge. To be sure, postmodernism is often identified with claims that knowledge is a web of beliefs rather than a Cartesian framework of foundational knowledge, with the idea that instead of a single totalizing discourse, we have a multiplicity of competing and contradictory language games in which we express ourselves and our views about the world. ${ }^{21}$ Lyotard even goes so far as to define postmodernism as a hostility to the idea of a master narrative. ${ }^{22}$ However, it is this very epistemological interpretation that leads one to think that postmodernism is merely another form of relativism dressed up in fancier clothing and thus leads one to debate postmodernism as a philosophical position like objectivism or relativism.

Yet a purely epistemological reading captures neither the meaning of postmodernist philosophy nor the experience of postmodern culture. Postmodernism is not simply a set of beliefs that persons happen to hold, although those beliefs are surely part of the cultural phenomenon we call postmodernity. Rather, they are those beliefs inscribed in ways of living that characterize the late twentieth century, and especially the life of postindustrial western societies. These features include the growth of mass media and telecommunications and the cultural effects that both mass media and telecommunications have

20. See, e.g., Sheryl Gross-Glaser, Firing Trends: Laid-off New York Associates Keep Headhunters Busy, A.B.A. J., Aug. 1990, at 23 (estimating that 750 to 1500 New York associates were fired in cutbacks and that associates are hampered in finding new jobs by their former firms' denial that layoffs were economically motivated).

21. See LyotaRD, supra note 2, at 10; Dennis Patterson, Postmodernism/Feminism/Law, 77 CORNELl L. REV. 254, 256-57 n.9 (1992).

22. LYOTARD, supra note 2 , at xxiv. 
had in society, as well as the rise of computer technologies and the creation of urban and suburban centers quite different from living arrangements found at the turn of the century. ${ }^{23}$ Postmodernism concerns the ways in which the material conditions of life have changed, not simply in the Marxist sense of ownership of the means of production, but in the more ordinary sense of how we go about living our daily lives - lives that are imbued with television, telephones, cable TV, international satellite hookups, film, video cassettes, and so on. Surely the epistemological programs of postmodernist philosophers are part of this cultural milieu. But they are only a small part. CNN and the modern enclosed shopping mall have had a much more significant defining influence on the postmodernist age than any of Richard Rorty's writings.

Thus, emphasis on cultural practices and ways of living is a key element of postmodern thought. If to imagine a language is to imagine a form of life, then language, thought, and the material conditions of life are inextricably intertwined. Knowledge is a set of language games, as opposed to a set of true beliefs; games imply activity, lived experience and interaction. Knowledge, then, is not something that we know but something that we do, or that is done to us. The Cartesian cogito becomes transformed: Instead of "I think therefore I am," we have "I think as I am."

For the modernist mind, this merging of thought and activity seems unnecessary and perhaps even bizarre. If there is such a thing as postmodernist philosophy, then there must be a set of postmodernist beliefs, and these must be true or false. From the standpoint of modernism, postmodernism is just another ideology another claim to totalizing discourse. ${ }^{24}$ But from its own perspective postmodernism cannot be such a discourse because it is not merely a set of beliefs, but also a cultural environment in which beliefs occur.

\section{IV}

What, then, is a postmodern constitutionalism? It should be quite clear from what I have said above that I do not think that the greatest relevance of postmodernism to American constitutional law lies in methods of interpreting the Constitution. Rather, I think constitutional lawyers need to understand postmodernism because they need to understand the cultural changes that have taken place around them

23. See Harvey, supra note 2; MARK Poster, The Mode of Information: PoststrucTURALISM AND SOCIAL CONTEXT (1990).

24. See Pierre Schlag, Missing Pieces: A Cognitive Approach to Law, 67 TEXAS L. Rev. 1195, $1245-46$ (1989) (describing how postmodernism is reinterpreted in rationalist accounts). 
in art, politics, technology, and economics. Just as one cannot understand modernism without understanding the Industrial Revolution and the spurt of technological and cultural change that accompanied it, one cannot understand postmodernism without understanding the particular technological and cultural changes in society that have accompanied it. Postmodernity is the era in which the industrial model of mass production is applied to the creation and distribution of symbolic forms. Therefore, we might approach the question of postmodern constitutionalism in the following way: How have changes in technology, communication, and the organization of living and working changed the public's understandings and practice of law, the Constitution, human rights, and democracy? How should the various social actors concerned with the Constitution (lawyers, judges, academics, legislators, citizens) understand the forms and practices of democratic self-government in light of the cultural changes occurring during the postmodern period, and what should they do in response to these changes?

In stating the question this way, I wish specifically to contrast my perspective with the view or assumption that constitutional postmodernism primarily involves questions of how to interpret the Constitution using postmodernist theories of interpretation or insights gained from understanding the "postmodern" or the socially constructed self. These projects may be useful ones. Yet they are only part of the story. To focus on postmodern theories of subjectivity without understanding the cultural and technological basis of change risks turning postmodernism into a sterile form of idealism.

Moreover, my analysis seeks to go beyond the concern with the "social construction of the subject" commonly associated with postmodernism in law. ${ }^{25}$ Without further development, there is the danger that such analyses will remain rooted in an overly idealist conception of culture. Shared symbols, values, discourses, or ideas are

25. The construction of the individual by culture is a key theme in the emerging category of postmodern jurisprudence. For recent examples of this scholarship, see STANLEY FISH, DoING What Comes Naturally: Change, Rhetoric, and the Practice of Theory in LiterARY AND Legal Studies (1989); Guyora Binder, Beyond Criticism, 55 U. ChI. L. Rev, 888 (1988); James Boyle, Is Subjectivity Possible? The Postmodern Subject in Legal Theory, 62 U. Colo. L. REv. 489 (1991); Rosemary J. Coombe, Room for Manoeuver: Toward a Theory of Practice in Critical Legal Studies, 14 LAW \& Soc. INQuIRY 69 (1989); Drucilla L. Cornell, Institutionalization of Meaning, Recollective Imagination and the Potential for Transformative Legal Interpretation, 136 U. PA. L. REV. 1135 (1988); Angela P. Harris, Race and Essentialism in Feminist Legal Theory, 42 STAN. L. REV. 581 (1990); Martha Minow, Identities, 3 YALE J.L. \& Human. 97 (1991); Patterson, supra note 21; Jeremy Paul, The Politics of Legal Semiotics, 69 Texas L. Rev. 1779 (1991); Gary Peller, The Metaphysics of American Law, 73 CAL. L. Rev. 1151 (1985); Pierre Schlag, The Problem of the Subject, 69 TeXAS L. REv. 1627 (1991); Steven L. Winter, Indeterminacy and Incommensurability in Constitutional Law, 78 CAL. L. REv. 1441 (1990); J.M. Balkin, Ideology as Constraint, 43 STAN. L. REv. 1133 (1991) (book review). 
implicitly assumed to be the "forces" of social construction. But no account is given of how this force operates in practice. In contrast, the analysis presented here is distinctly material in its concerns. It asks how changes in technology and culture create new opportunities for the exercise of power. It seeks to draw closer connections between the material conditions of life and thought by studying the technological re-creation of forms of life.

A postmodern constitutionalism, in my view, must ask how postmodern culture and technology have affected law as an institution: the way that the courts, Congress, and the executive interact with each other, and the way that law is understood, promulgated, argued about, experienced, and assimilated. How is information about constitutional rights distributed and spread? What changes have occurred in the ways in which politics is organized, and in the ways in which laws are debated publicly or within government institutions? How have advances in technology changed the possible forms of power, control, and surveillance? What effect has mediazation wrought on the practice of American democracy? These are the key questions for a postmodern constitutionalist.

We can divide this general inquiry into several issues.

\section{A. Technological Changes Affecting Democratic Institutions}

The Constitution regulates democratic self-government. Yet democracy as a set of institutional practices has changed greatly since the Second World War and especially since the 1960s and 1970s. Political action committees have taken advantage of developments in computerization and data processing to manipulate the political process in ways heretofore undreamed of. The past twenty-five years have seen the increasing concentration of media industries into multinational conglomerates. ${ }^{26}$ What effects will these changes have on our understanding of free speech and traditional expectations about the press as guardians of democracy? What does the First Amendment mean in an age of increasing economic concentration in media industries, or in an age of organizations specifically devoted to mass distribution of political messages?

Perhaps even more important from the standpoint of postmodernist theory, mediazation has fundamentally changed the terms of public debate. ${ }^{27}$ The movement from newspapers to televi-

26. See Ben H. Bagdikian, The Media Monopoly (3d ed. 1990); Kellner, supra note 10, at 80-90; LuCAS A. POWE, JR., The Fourth Estate AND the Constitution 201-03 (1991); THOMPSON, supra note 4, at 193-205.

27. KellNer, supra note 10, at 111-32; ThOMPSON, supra note 4, at 218-71. For general 
sion broadcasting as the major source of public information has changed the nature of information received by the public. It has changed the public's expectations of political behavior and the content and form of political communication. ${ }^{28}$ What constitutional analysis should apply to regulation of public elections in the era of the sound bite, the photo opportunity, and the media event? Technological improvements have also made possible sophisticated polling techniques, whose power has made them indispensable to modern political discourse. What effect have these developments had on the democratic nature of public opinion? Has virtually instantaneous polling created a feedback loop of public expectations about expectations that will lead to volatility in public opinion or put in doubt the meaning or the authority of "majority preferences"? Worse yet, has the very concept of a true "public opinion" that is not manufactured or simulated lost its meaning in the postmodern age? ${ }^{29}$

Mediazation has not only affected the form in which information about public affairs is conveyed to the public; it has also had a profound effect on the presentation of the self in public life. Political fortunes can vanish overnight by the slightest slip of the tongue when it is broadcast nationwide..$^{30}$ Mediazation has also permitted revelations about politicians to be broadcast quickly and widely in simplified and highly charged symbolic forms. Similarly, the public's expectations about what will or will not be revealed about political life, and hence what aspects of private life are relevant, have surely been affected by the mediazation of politics. ${ }^{31}$

studies, see Luke, supra note 10; DAN NIMMo \& JAMES E. Combs, Mediated Political REALITIES (2d ed. 1990).

28. A classic account of how "pseudo-events" are created for media consumption is DANIEL J. Boorstin, The Image (1962). GuY Debord, The Society of the Spectacle (1975), describes how mediazation contributes to the development of spectacles geared for popular consumption. On the transformation of political election campaigning due to mediazation, see Kellner, supra note 10, at 148-58; Joe McGinniss, The Selling of THE President (Penguin Books 1988) (1969).

29. Jean Baudrillard's critique of polling and mass media, for example, goes beyond charges of manipulation or distortion of public preferences in modern democracies. Baudrillard argues that the mass media have eliminated the division between political simulation and reality, so that simulation itself has become political reality. It follows that media and polling techniques do not distort the political process - they are constitutive of the political process. It becomes impossible to speak of the distortion of the political process when the thing that is supposed to be distorted is created by the very thing that is supposed to be distorting it. Thus, we no longer even have the comfort of believing that opinion polls manipulate public opinion, because we can no longer isolate political reality, human will, or human nature as something that could be corrupted or distorted by the media reports that create both political reality and our political selves. See Jean Baudrillard: Selected WRITINGS 208-10 (Mark Poster ed., 1988). For an introduction to Baudrillard's views, see Christopher Norris, Lost in the Funhouse: Baudrillard and the Politics of Postmodernism, in POSTMODERNISM AND SocIETY, supra note 12, at 119-53.

30. Thомpson, supra note 4 , at 247-48.

31. Thus, it is possible that the "New Puritanism" that has beleaguered political candidates 
We must also ask how mediazation has affected methods of interaction among various government officials and branches of government. Does the ability to manipulate symbols in the media alter the ways in which politicians achieve compromises behind closed doors? Does it increase opportunities not only to inform but also to mislead the public about the nature of proposed legislation? Has mediazation increased executive power disproportionately because of the executive's greater opportunities for manipulation of symbolic forms? Finally, has mediazation helped to impose increasingly insuperable barriers to entry for challengers to incumbent politicians or for persons without access to considerable wealth? The study of the Constitution has always had to confront structural effects and limitations on self-government and democratic ideals. A postmodernist constitutionalism, then, simply asks whether the technological and cultural features of the present era have altered these structural effects or limitations or added new ones of supervening importance.

The question of mediazation must also be confronted by anyone who seeks to ground democratic theory on any form of dialogism or informed public discourse. Mediaized communication conveys information on a mass scale, but unidirectionally; ${ }^{32}$ it arrives instantaneously, but in the form of highly charged symbols and sound bites. Mediazation of political culture thus jeopardizes the kind of neutral dialogism that many contemporary political theorists view as necessary to the success of their projects. ${ }^{33}$ Ironically, these philosophical projects do not always consider the extent to which technology has rendered their dreams impossible of attainment, or even worse, wholly irrelevant. Yet no theory of democracy can succeed unless it takes these technological changes in dissemination of information into account. Dialogism may already have died the death of a thousand

in recent years may be a function not only of changing public values but also of the gradual change in public and private conceptions of self traceable to mediazation. See THOMPSON, supra note 4 , at 246-48. On the recently lamented phenomenon of "pack journalism," in which journalists devote inordinate amounts of coverage to sensational allegations about the private lives of public figures, see LarRY J. SABATo, FeEding Frenzy (1991).

32. Mark Poster, Foucault, MarXism, and History 115 (1984); Thompson, supra note 4, at 227-28; L. A. Powe, Jr., Mass Speech and the Newer First Amendment, 1982 SuP. CT. REV. 243.

33. Here we should distinguish ideal or "as if" dialogism from actual dialogism. We must distinguish theories that attempt to justify political structures as if they were the result of an ideal dialogue or deliberative process that did not actually occur from theories that insist legitimacy flows from actual deliberation and dialogue, and therefore seek to make the actual political process more deliberative or closer to an ideal dialogic situation. Postmodern culture presents obvious problems for the latter group. However, the postmodern experience also presents problems for ideal dialogic theories, because it reveals the nonnatural, historically contingent, and technologically situated nature of our assumptions about dialogue and deliberation. 
sound bites. ${ }^{34}$

\section{B. Technological Changes Affecting Public Perception and Participation in Law}

What effect have the rise of mass media and the industrialization of symbolic forms had on the way that the public understands their legal rights and their ability to participate in the legal system? One might well invent, by analogy to the phenomenon of "sound bites," the concept of "law bites," or symbols of the legal system that have become the common cultural coin of the general public. A classic example of the law bite in operation are reports of motorists arrested by Canadian police who repeatedly insisted that their Miranda rights be read to them. ${ }^{35}$ Mass broadcast of American police shows (and later L.A. Law) has apparently altered the public's perception of the criminal and civil justice system, and not only in America. These symbolic representations of law become the common forms of discourse and benchmarks of expectation about law among the lay public. ${ }^{36}$ The growth of cable networks like C-SPAN, CNN, and Court TV, and extensive coverage of trials on television, has increasingly subjected legal controversies to a process of mediazation that has already infected politics. Judges, prosecutors, and even witnesses become media

34. An innovative attempt to meet the crisis in democratic self-government described here comes from a political philosopher who does believe in the importance of dialogue in refining and reaching a legitimating consensus in liberal democratic societies. Professor James Fishkin has argued that a citizen jury or "deliberative opinion poll" of 600 randomly selected Americans should be allowed to meet with prospective presidential candidates in a weekend retreat. The purpose of the event would be to force face-to-face dialogue and extended discussions of policy issues between candidates and citizens. Although the event would be televised, the personal interactions between candidates and voters would discourage much of the presentation management that modern political campaigning through the mass media encourages. Extended face-toface interaction with candidates would be designed to give the participants personal knowledge of the characters, strengths, and weaknesses of candidates that is hard to obtain from staged campaign events. After the retreat, the participating citizens would be polled on their views about the candicates as well as on public policy issues, and this information would be made available to the general public. The citizen jury model is described in detail in JAMEs S. Fishrin, DemocRacy and Deliberation: New Directions for Democratic Reform (1991). A candidate's retreat along the lines of Fishkin's model was actually planned for the 1992 presidential campaign, and would have taken place in January of 1992, but fell through because funding for the project could not be procured from interested media organizations. A second attempt is currently being planned for 1996 . Communication from James S. Fishkin to author.

35. Herbert H. Denton, Canada Turns to U.S. on Bill of Rights Issues; Meese Joins Debate With Speech, WASH. POST, Aug. 7, 1986, at A30 (noting that "[m]any Canadians who have spent hours of their childhood watching police on American detective television read suspects their Miranda rights," have mistakenly demanded the same warnings from Canadian police officers).

36. Cf. Rosemary J. Coombe, Objects of Property and Subjects of Politics: Intellectual Property Laws and Democratic Dialogue, 69 TEXAS L. REv. 1853, 1861-65 (1991) (noting how in postmodernist culture, shared cultural symbols taken from television shows, movies, advertising campaigns, and mass-produced consumer goods become shared resources for construction of social meaning). 
stars; Senate confirmation hearings are scheduled to mesh with the demands of prime time viewing. ${ }^{37}$ Changes in substance soon follow those of form; indeed, at points the Thomas confirmation hearings were difficult to distinguish from a particularly sordid episode of Geraldo.

With the mediazation of law and legal processes, the products of the Supreme Court and lower courts become transformed in the public eye in the same way as the work of politicians. When Supreme Court arguments are finally televised, this mediazation may well be on the way to its culmination. In the interim, the experience of televised confirmation hearings and criminal trials gives us some idea of the brave new world of media-saturated law that awaits us. Ironically, then, the divide between legal and political discourse may eventually be dissolved not by the efforts of critical legal studies, but by those of Ted Turner and the Cable News Network.

As noted above, media communication allows mass participation, but only unidirectional participation, because viewers can watch, distanced in time and/or space, but cannot otherwise interact with the sender. In the same way that mass media create the possibility of unidirectional political participation on a mass scale, so too the mediazation of law will create opportunities for manipulation of symbolic forms, commodification and spectacle. If the Bork hearings symbolized a sea change in the confirmation of Supreme Court nominees and a blurring of lines between judicial and political candidates, as many have argued, this is not simply due to the bad faith of Bork's political opponents. Rather, I suggest that it is at least partly due to the technological and cultural changes of the postmodern era, which made mass political organization and mediazation of the confirmation process possible. Opposition to Bork was raised through forms of mass politics that would have been impossible without contemporary quasiindustrial methods of political organization or the use of mass media for distribution of messages. ${ }^{38}$ Hence, the Bork nomination, for all the things that it symbolized, may also have symbolized a breakthrough in the mediazation of law. In this way Bork, the pessimistic modernist, was defeated, for good or ill, by forces unleashed by the postmodern

37. See Helen Dewar, Democrats Criticized for Strategy on Thomas; Approach in Hearings Called Too Cautious, WASH. PosT, Oct. 20, 1991, at A11 (noting Bush administration demands to schedule Clarence Thomas' testimony during prime time, while Professor Hill's testimony was placed during the day when most working people could not watch).

38. See Robert Bork, The Tempting of America: The Political Seduction of the LAW 267-349 (1989); ETHAN BRONNER, BATTLE FOR JUSTICE: HOW THE BORK NOMINATION SHOOK AMERICA (1989). 
era. ${ }^{39}$

\section{The Industrialization of Legal Production}

I have argued above that a key postmodernist phenomenon is the application of methods of industrial production to symbolic forms, intellectual products, and the life of the mind in general. Information and symbol manipulation become important commodities or sources of wealth. We can see these features occurring in the legal profession as it exchanges an earlier professional ethic for an industrial professionalism. Examples of the industrialization of symbolic legal forms include the growth of large law firms which employ large scale discovery practices, computerization of documents, and other quasi-industrial methods of litigation and work production. As noted above, in employer and employee relations, we are seeing the development of a quasi-industrial model whereby lawyers are hired, fired, and laid off like industrial workers. ${ }^{40}$

The judicial chamber and the academy have not escaped the effects of postmodern industrialization of symbolic forms, although these influences are manifested in a somewhat different manner. In the judiciary, we see increasing pressures for application of quasi-industrial methods to the administration of justice. This is evidenced not only in the increasing limitation of time for oral argument, the streamlining of dockets, and administrative regulations designed to minimize caseloads, but also in the increased use of clerks to write opinions and

39. As in the case of the Bork nomination, the success of the Thomas nomination appeared to turn on the views of voters in a handful of southern and midwestern states represented by the few senators who remained publicly undecided. Thus, questions of Thomas' legal qualifications (about which even some of his supporters had doubts) were shelved in favor of the sort of issue that could be packaged for mass consumption and conveniently played out in front of the television cameras - Thomas' sexual behavior. Consequently, the struggle over the nomination inevitably reduced to a struggle over the public's view of the seriousness of the charge of sexual harassment and the comparative credibility of Judge Thomas and Professor Hill. What were by now relatively standard techniques of media manipulation were used to great effect in this cause. Thomas' now-famous "hi-tech lynching" speech, evoking powerful imagery of his destroyed reputation and offering barely concealed accusations of racism against his white opponents, apparently helped to turn the tide in his favor, as did the vigorous attacks on Professor Hill's credibility and emotional stability launched by Senators Hatch, Simpson and Specter. With onthe-spot polling techniques showing a decided swing in voter sympathy towards Thomas after his testimony, the Senate's confirmation was assured. One need not label these events "postmodern" to wonder at what they portend for the future of American constitutionalism. One need merely sit in front of the television and watch.

40. This process of industrializing legal employment and legal production is no doubt related to, but should not be confused with, a perceived decline in professional standards of practice. While the "industrialization" process is a product of the twentieth century, and especially the late twentieth century, laments about the loss of professional values in the practice of law have occurred continuously throughout the history of the American bar. 
the lack of time for judicial study and reflection - in short, the creation of an industrial model of adjudication.

In the academy, we can witness the increasing need to evaluate work in terms of discrete units of production. Thus, the equivalent of billable hours in the law firm are articles in the legal academy. Academic organizations are increasingly structured to reward persons who produce measurable units of production. Such a process elevates objective measurements of quantity over subjective measurements of quality, on the grounds that quantity is more easily measurable. This produces increasing pressure for academics to publish, not because it will increase the valuable knowledge of mankind, but as a symbol of scholarly production. The term "productive scholar" thus comes to mean the scholar who produces a continuous stream of units of production, rather than the scholar who produces meaningful work.

\section{The Fragmentation of the "Public Sphere" of Legal Discourse, and the Rise of "Legal Theory"}

One of the most useful of Habermas' conceptions is the idea of a public sphere of discourse arising with the Enlightenment. ${ }^{41}$ Through this public sphere the great issues of the day were debated in coffee houses, salons, literature, and eventually through the earliest forms of mass media. 42 An important consequence of the postmodern age is the destruction or at least transformation of this public sphere due to the rise of mass communication, which permits only unidirectional reception as opposed to the participatory dialogue upon which the traditional public sphere depended. ${ }^{43}$ We might, by analogy, consider whether there has been a "public sphere" for legal discourse in this country. I would argue that such a public sphere, in which lawyers, judges, and the legal professoriat engaged in a more or less continual discourse on the growth, restatement, and reform of positive law, existed at least from the end of the nineteenth century. ${ }^{44}$ This public sphere continues even today, although the growth of mass media as a method for distribution of legal information (Lexis, Westlaw, and computer satellite broadcasts of CLE programs) may also threaten its disintegration. But perhaps an equally important feature of the disin-

41. JÜrgen Habermas, The Structural Transformation of the Public Sphere: AN INQUIRY INTO A CATEGORY OF BOURGEOIS SOCIETY (Thomas Burger \& Frederick Lawrence trans., 1989).

42. ThOMPSON, supra note 4, at 111.

43. See id. at 113-20.

44. See Edward L. Rubin, The Practice and Discourse of Legal Scholarship, 86 Mich. L. REV. 1835 (1988). 
tegration of this public sphere of legal discourse is the development of the special status of the legal academic. The legal academy has, for the past twenty-five years at least, become increasingly interdisciplinary. At the same time, it has become increasingly distanced from the work of actual lawyers and judges. Pierre Schlag's diatribes against normative legal scholarship ${ }^{45}$ attack the retention of the form of the discourse of the public sphere after the sphere itself has dissolved. Schlag's attack is well taken with respect to certain types of law, although a remnant of a public sphere still remains with respect to other types, particularly local and commercial law (with the caveat that this public sphere has also been transformed by mediazation). Nevertheless, constitutional law is perhaps the best example of how a public sphere of legal discourse that once included practitioners, judges, and academics has largely disintegrated. In constitutional law, we clearly see the fragmentation of legal culture into an increasingly conservative body of judges and an academy that is quite liberal and whose work is increasingly irrelevant to the actual practice of constitutional adjudication. In my view, this is the best explanation of the puzzle I began this essay with. Postmodern legal culture is not necessarily a culture of lawyers and judges who embrace postmodern interpretive theories, but rather a legal culture mimetic of postmodernity: fragmented, decentered, diffused.

As the judiciary becomes increasingly conservative, we witness increasing self-absorption within the legal academy and its increasing isolation from legal practice. Once again, these phenomena occur in differing degrees in different areas of the law, but they are especially pronounced with respect to constitutional scholarship. As a result, a new class of academics arises who have little or no interest in practical political activity, practical law reform, or even practical restatement of the law. Thus, the postmodern period is marked by the creation of a species of legal scholarship known as "legal theory." As a result of the rise of interdisciplinary scholarship, genres of scholarship defined by traditional practice areas (e.g., contracts, torts) are replaced by scholarly genres defined by theoretical allegiances (e.g., law and economics, feminist legal theory), which may cut across traditional doctrinal areas or simply be irrelevant to them. ${ }^{46}$ As Sanford Levinson and I have described elsewhere, these developments create opportunities for frag-

45. Pierre Schlag, "Le Hors de Texte, C'est Moi": The Politics of Form and the Domestication of Deconstruction, 11 Cardozo L. Rev. 1631 (1990); Pierre Schlag, Normative and Nowhere to Go, 43 STAN. L. Rev. 167 (1990); Pierre Schlag, Normativity and the Politics of Form, 139 U. PA.

L. REV. 801 (1991); Schlag, supra note 25.

46. Levinson \& Balkin, supra note 8 , at 1652-53. 
mentation not only between the legal academy and legal practitioners, but within the legal academy itself. ${ }^{47}$

The flip side of academic alienation from practitioners is academics' increasing lack of respect for the products of judges, legislatures, and administrative agencies. Academics increasingly recognize, or rather assume, the product of these bodies is written by clerks, politically biased, incompetently reasoned, or all three at once. At the same time, they attempt to redescribe law in terms of ideas that have no possible chance of being enacted into legal practice, at least absent a miraculous mass indoctrination of the judiciary. We thus witness the creation of a "shadow constitution" by progressive scholars, in which they declaim what the Constitution really means in the face of the increasing likelihood that it will never mean that in practice.

\section{E. Technological Changes Affecting Privacy and Surveillance Both by the State and by Private Organizations}

Finally, a postmodernist constitutionalism must come to grips with the effects of technology on privacy, and, more generally, on autonomy itself. ${ }^{48}$ Each of us, whether we recognize it or not, produces traces of her activities in material form, just as an animal leaves a trail in the dust where it travels. These traces are signs, but, equally important, they are material signs. If one were able to capture and reconstruct increasing numbers of a person's material traces, one would have an increasingly full picture of that person - not only of her locations and activities, but even of her thoughts, beliefs, and desires. With the growth of computers, electronic information collection and retrieval systems, mass media, electronic recording equipment and forensic science, it is now possible to organize an incredible number of facts about individuals from the traces they leave behind them. For example, credit card purchases can be recorded in a data bank that can be used to create a consumer profile of customers and trace their

47. Id.

48. There is now an increasingly large and important body of scholarship on technology and privacy, some of which is self-consciously within the body of postmodernist scholarship, but much more which is not. In the latter category, the pathbreaking work is ALAN F. WESTIN, PRIVACY AND FREEDOM (1967). Many philosophical and economic treatments of privacy have emerged recently, although they do not always emphasize technological issues. E.g., KIM L. Scheppele, Legal SeCrets (1988); Richard A. Epstein, Privacy, Property Rights, and Misrepresentations, 12 GA. L. REV. 455 (1978); Ruth Gavison, Privacy and the Limits of Law, 89 YALE L.J. 421 (1980); Richard A. Posner, Privacy, Secrecy, and Reputation, 28 BuFF. L. ReV. 1 (1979); Richard A. Posner, The Right to Privacy, 12 GA. L. Rev. 393 (1978). A good introduction to the legal issues of technology and privacy is Spiros Simitis, Reviewing Privacy in an Information Society, 135 U. PA. L. REV. 707 (1987). Postmodern treatments have largely been inspired by the work of the historian of ideas Michel Foucault on punishment and surveillance. See infra notes 49,50 . 
movements. The use of electronic pricing codes by checkout clerks provides a method not only of controlling inventories but also of compiling information about purchasers' tastes and preferences. The growth of computerization has made possible a revolution in the collection and analysis of information whose scope could hardly have been imagined twenty years ago. Matching information from different databases makes increasingly possible the production of new kinds of surveillance and control. This is the nightmare of Bentham's Panopticon - a prison where each individual's mere knowledge that her every movement is known to others is sufficient to effect behavioral control without the use of physical force. ${ }^{49}$ A social Panopticism of the kind envisioned by Foucault is now made frighteningly possible by contemporary technological advances. ${ }^{50}$ In this way, knowledge, or more correctly information encoded in material form, creates ever new sources of power and ever new possibilities for control in the postmodern age.

These developments pose significant problems for constitutional theory. Both the state and private individuals will have control over the new technologies of information collection and surveillance. What limits should be placed on the ability of public and private organizations to collect, organize, and distribute such information? Traditional First Amendment philosophy has asserted that the best weapon against speech we do not like is still more speech. Does this philosophy continue to make sense in an era of new information and surveillance technologies? Will increased availability of information about the most detailed aspects of our lives lessen the dangers of control through surveillance or data compilation? Or is the problem precisely the opposite - that the availability of the information is itself the problem? Do traditional liberal notions of autonomy continue to make sense in an age where control of information processing increasingly means new forms of control over individuals themselves? Or has the liberal ideal of the free market of ideas now turned in on itself and created a new form of totalitarianism, a prison constructed from access to information rather than from steel bars?

These issues strike at the heart of liberal political philosophy. Pri-

49. Michel Foucault, Discipline and Punish: The Birth of the Prison 200 (Alan Sheridan trans., Vintage Books 1979) (1975). The Panopticon was a prison constructed as a quadrangle with a high tower in the center; the guard in the tower could watch the prisoners, but they could not see the guard. Thus the prisoners knew that they were constantly subject to surveillance, but they could not tell exactly when surveillance was taking place. Id. As a result, this technology "induce[s] in the inmate a state of conscious and permanent visibility that assures the automatic functioning of power." Id. at 201.

50. See PoSTER, supra note 32, at 102-03, 165-67; POSTER, supra note 23, at 69-98. 
vacy is deeply related to notions of individualism and individual autonomy. Each of us has both a public and a private self; the public self we reveal to the world, and the private self we retain control over by withholding it from others. Our ability alternatively to provide or withhold aspects of our private selves preserves and constitutes our autonomy. Exchanges of private information signal intimacy and trust, and their disclosure to third parties is usually thought a sign of betrayal. But the ability to withhold information about the private self is not wholly a natural attribute of existence - it is technologically circumscribed and determined. What will happen to the fabric of intimate relations in a world in which technological advancement increasingly shrinks the domain of the private self? Will traditional assumptions about personal privacy (and hence autonomy) still make sense, or will they have to be reimagined in wholly different ways? And if this is so, what will happen to a constitutional jurisprudence based on eighteenth-century notions of privacy and autonomy that assumed a world without our present technological advances? Again, it is important to stress how these issues go beyond standard assertions about the social construction of the subject. We are concerned here with the material linkages of power; we are concerned with how forms of technology create new forms of power that will inevitably shape our own understandings and expectations about ourselves. If changes in material conditions can so alter or undermine our conceptions of privacy, it is neither our shared ideas nor their social construction that become the key issues, but rather technological change and who has control over its shape and direction.

\section{V}

Postmodernism is sometimes described as a rejection of the Enlightenment and the values of the Enlightenment. ${ }^{51}$ I prefer to see postmodernism as a partial continuation of the Enlightenment, and a reevaluation of what was good and bad about the Enlightenment project. The Enlightenment sought to free humanity from the chains of unthinking tradition and religious bigotry. It sought to master the world through science and remake the world according to the dictates of reason. It sought to understand and to recast society in rational and scientific terms, and it was confident about the ability of the human intellect to do this. Two centuries later, humanity is imprisoned by

51. See, e.g., Alex Callinicos, Reactionary Postmodernism?, in PosTMODERnism AND SocIETY, supra note 12, at 97, 97-100; Anthony Carty, Introduction: Post-Modern Law, in PosTMOdern Law: ENLightenment, Revolution and THE Death of MaN 1 (Anthony Carty ed., 1990). 
new chains that the Enlightenment forged for us. These are the chains created by science, technology, and rationality, which in the course of liberating us subjected us to new forms of control, bureaucracy, mediazation, suburbanization, and surveillance. We still need liberation, we still need emancipation, but now it is from the products of our previous emancipation - from computer data bases, sound bites, political action committees, voodoo economics, electronic surveillance, commodified video images, and the industrialization of professional culture. The emancipation we now require cannot be on the same terms as those proposed by the Enlightenment. It must, at least in part, be a rejection of the terms by which we freed ourselves from pre-Enlightenment thinking.

Moreover, as I have tried to suggest in this essay, viewing postmodernism as a reaction to the Enlightenment neglects a second, equally important issue. The Enlightenment is identified primarily with ideas and with the quest for knowledge. After all, the very motto of the Enlightenment, as announced by Kant, was "Dare to Know."52 Yet there was much more to modernity than Enlightenment. These ideas did not exist in a vacuum but were rather part of increasingly rapid technological changes that brought on profound changes in the way that individuals led their daily lives. ${ }^{53}$ The material conditions in which knowledge and thought were instantiated were just as important to modernity as were Enlightenment ideals themselves. Indeed, these technological changes were in some ways even more important than the liberal humanist ideology of the West. This fact is crucial to understanding the meaning of postmodernity in places outside of North America and Western Europe. The technological progress of modernity reached further throughout the world than its associated Enlightenment ideals ever did. The automobile and the television have traveled to places that never heard of John Stuart Mill. Perhaps the most telling revenge of modernity on itself were scenes broadcast to the United States of the Ayatollah Khomeini's followers carrying handpainted signs (in English) calling for "Death to the United States." Fundamentalist cultures had also learned to manipulate the broadcast media produced by western technology in their war against the Enlightenment values of the West. Our humanist ideals may rise and fall, but our technology goes forward forever, mindlessly and powerfully. If the motto of the Enlightenment was "Dare to Know,"

52. IMMANUEL KANT, What is Enlightenment?, in FOUNDATIONS OF THE METAPHYSICS OF Morals \& What is ENLIGHTENMENT? 286 (Lewis W. Beck trans., 2d ed. 1955).

53. See Marshall Berman, All That is Solid Melts into Air: The Experience of MODERNITY 18-19 (1982). 
the motto of the post-Enlightenment should be that Knowledge is Material. It is with that principle, perhaps, that a postmodern constitutionalism must begin. 